\title{
A Study of Relationship between Leadership Styles of Principal and Teacher Effectiveness
}

\author{
Dr. Mohan Lal 'Arya' \\ [M.A (Geography, Edu. \& Eng.), M.Ed., M.Phil.(Edu.), NET(Edu.), Ph.D.(Geog.)] \\ Assistant Professor, Department of Education \\ Additional Charge, Head of Department, Department of Geography, IFTM University, Delhi Road, Moradabad
}

\begin{abstract}
Now days, most of the Principals are facing problems of applying suitable leadership style in their administration, reported by the schools. Therefore, applying suitable leadership may assist Principals to solve the confusion due to the overlapping of work occurred in work practice, administration and ordering or commanding among the top level of management team. The Path-Goal Theory was used as the main theory to support present study. The objectives of the present study were to investigate the leadership styles of school Principal that affecting teacher effectiveness. The present study employed quantitative method survey design using questionnaire as a tool. Simple random sampling technique was used in the present study. A total of 128 Principals and teachers from schools affiliated to U.P. Board. Data was analyzed using frequency, percentage; mean value, standard deviation, correlation Pearson product moment, and multiple regression Stepwise method. Findings showed that there are two types of leadership styles of school Principal, namely supportive leadership and participative leadership styles which have significantly affecting teacher effectiveness. In addition, both leadership styles have been jointly predicted teacher effectiveness at 56.80 percent at the significance level as 0.01 . In conclusion, in order to increase teachers' working effectiveness, administrators should promote, practice, and improve these two leadership styles, namely supportive leadership and participative leadership styles.
\end{abstract}

Keywords: Leadership styles, School Principals, Teacher effectiveness, Relationship

\section{Introduction}

With the advent of $21^{\text {st }}$ century, tremendous changes have been witnessed in Indian Society. Growing field of IT and other Technological revolution have changed the picture of past Indian. India is facing different types of challenge, which are of great significance from the development point of view. In this context, education is the most potent instrument of imparting knowledge to people, providing them a sense of purpose and develops qualities and values in them, which are essential for building a strong, cohesive and enlightened nation. In the history of mankind, education has always been considered a potential means and strong base for the development of human society. Through the development of attitude, values, capabilities, knowledge and kill, education provide strength and vitality to people. It enables them to face the challenges of time resolutely and to contribute to the social development most effectively. In democratic society like Indian, education has to be the main stay of all national endeavors. With the help of a powerful instrument (education), society has to perform many responsibilities concerning with its citizen. For this, society establishes and develops many organizations on course of time to achieve a variety of goals and objective. They serve various social, economic, cultural, political, religious and other purposes. Obviously they differ in their structure, finding, scopes, sizes, control and management and also in efficiency and outcomes. Schools and college are unique institution designed to achieve specific goal for preparing good citizens.

Now each and every country I going on the path of technological advances and with it many problems such as how to grow more foods, population problem, IT problem and material sources problem etc. have been crisped values out. These are as a result of changes in citizen values, attitudes, customs and practices, work habits, methods and the way of thinking. So, this responsibility goes on the shoulders of schools and colleges both on the field of society's norms and world at large. The success of this work depends upon effective function of institutions.

In India, Science and Technology have been in use since long. But in recent years, India as a nation is heading for rapid individualization based on the use of high technology. Such effort needs automation and the use of computers. These efforts have two major requirements. First, there is a need of highly trained experts, who can build indigenous system of science and technology; second, scientifically literate citizens, who can take decisions about the proper use of science and technology.

The current transformation of technology information has caused the flow of communication to be world boundless that affecting traditional paradigm to face the challenges of various types of crisis. This transformation definitely would have major effect on human development. In Moradabad U.P, human development and strength of grass root economic are the two significant strategies for solving social crisis. Education system is the major mechanism to support these strategies. Hence education management has to play important roles in solving the occurred problems not only for the sake of Indian society development but also aimed to develop human resource at national level. As a result, it is a key responsibility for educational administrators (Principal) to manage school organizations efficiently according to educational policies as well as educational administration and management.

\section{Review of Related Literature}

Rao (1995) studied relationship between teacher effectiveness, creativity and inter-personal relationship of teachers. The findings revealed that no significant relation 


\section{International Journal of Science and Research (IJSR) \\ ISSN (Online): 2319-7064}

Index Copernicus Value (2015): 78.96 | Impact Factor (2015): 6.391

was found between teacher effectiveness and the income or years of service of the teacher. However significant relations were found between teacher effectiveness, creativity and interpersonal relationships of teachers and significant differences existed between rural and urban teachers with reference to interpersonal relationship. Sweetlin Rajam Amsarani (2000) conducted a study on teacher effectiveness of second language teachers in higher secondary schools. The study used a sample of 50 teachers and 1000 students selected from various higher secondary schools. The major finding of the study is that Teacher Effectiveness of P.G. English teachers is neither low nor high, just moderate; in terms of cognitive aspect is just moderate; in terms of affective and psychomotor aspects it ranges from moderate to low. Amandeep and Gurpreet (2005) conducted a study of teacher effectiveness in relation to teaching competency. The results reveals that female teachers are more effective in their teaching than male teachers; male and female teachers do not differ significantly as far as their teaching competency is concerned; and variable of teaching competency plays significant role in teacher effectiveness of teachers. Shweta Aggarwal (2012) conducted a correlation study of teacher effectiveness and job satisfaction of higher secondary school teachers. The study concludes that all types of government school teachers are endowed with more teacher effectiveness than all types of aided and non-aided school teachers, besides finding that government school teachers have better professional and academic knowledge and better relationship with pupils, principles and parents.

\section{Statement of the Problem}

The problem has been stated as follows: - "A Study of Relationship between Leadership Styles of Principal and Teacher Effectiveness.”

\section{Objectives of the Study}

The main objectives of the present study are following: -

1) To study the leadership styles of Principal and teacher effectiveness.

2) To study of relationship between leadership styles of Principal and teacher effectiveness.

\section{Methodology of the Study}

A total of 128 respondents consist of 64 Principals and 64 teachers schools affiliated to U.P. Board are selected equally by utilizing sample size determined. Meanwhile, simple random sampling is employed. The instrument used in the present study is a set of questionnaire. Leadership styles of Principal consist of directive, supportive, achievement oriented and participative leadership. However, teacher effectiveness comprised of four domains. They are job satisfaction, team working, organizational commitment, and student's quality. Descriptive statistic including frequency, percentage, mean and standard deviation was used in the present study. Furthermore, inferential statistic like Karl Pearson's correlation used to explain the relationship between leadership styles of Principal and teacher effectiveness.

\section{Variables of the Study}

In the present study, two main variables these areleadership Style and Teacher Effectiveness. The independent variable is leadership styles of Principal. The types of leadership style consist of directive leadership, supportive leadership, achievement oriented leadership, and participative leadership. Teacher effectiveness is the dependent variable and it measures four domains of teacher effectiveness. The principals and teachers' perception of leadership styles of school Principal is important as it affects the $\mathrm{f}$ teacher effectiveness. The four domains of teacher effectiveness are job satisfaction, team working, organizational commitment, and student quality.

\section{Result and Interpretation}

Leadership style: - In the table n. 1 shows the mean scores and standard deviations of the four types of leadership style by respondents. As in table n.-1, the mean value for the four types of leadership style ranged from 4.01 to 4.18 . The highest mean value was supportive leadership style 4.18. The next highest mean value was participative leadership style 4.10. This is followed by achievement-oriented leadership style mean value is 4.03 . The lowest mean value was directive leadership style 4.01 and the highest S.D. was Participative leadership style 0.67 and lowest S.D. was Supportive leadership style and Directive leadership style.

Table 1: Leadership styles of Principal

\begin{tabular}{|c|l|l|c|}
\hline & Leadership styles & Mean value & S.D. \\
\hline 1. & Supportive leadership & 4.18 & 0.56 \\
\hline 2. & Directive leadership & 4.01 & 0.56 \\
\hline 3. & Achievement-oriented leadership & 4.03 & 0.62 \\
\hline 4. & Participative leadership & 4.10 & 0.67 \\
\hline
\end{tabular}

Teacher's Effectiveness: - In the table n.-2 presents the mean value and standard deviation of the four domains of teacher effectiveness. As in table n.-2, the mean value ranged from 4.12 to 4.32 . The highest of teacher effectiveness was job satisfaction domain 4.32. Team working and organizational commitment teacher effectiveness domains were obtained the same value of effectiveness 4.29 and 4.29. But the lowest teacher effectiveness was student quality 4.12.

Table 2: Teacher's Effectiveness

\begin{tabular}{|c|l|l|c|}
\hline & Teacher's Effectiveness & Mean value & S.D. \\
\hline 1. & Job satisfaction & 4.32 & 0.60 \\
\hline 2. & Team working & 4.29 & 0.60 \\
\hline 3. & Organization commitment & 4.29 & 0.57 \\
\hline 4. & Student quality & 4.12 & 0.50 \\
\hline
\end{tabular}

Relationship between each type of leadership style and teacher effectiveness: - in the table-3 presented the Pearson correlation coefficient to show the relationship between the four types of leadership style and teacher effectiveness and the correlation results between the four types of leadership style and teacher effectiveness showed a significant relationship (0.01), with strength of association to Low, Moderate, Strong, Very Strong, Perfect and Very Perfect Relationship as well as Positive and Negative. 


\section{International Journal of Science and Research (IJSR) \\ ISSN (Online): 2319-7064}

Index Copernicus Value (2015): 78.96 | Impact Factor (2015): 6.391

Table 3: Relationship between each type of leadership style and teacher effectiveness

\begin{tabular}{|l|l|l|l|}
\hline S.N. & Strength of association & Positive & Negative \\
\hline 1. & Low & 0.10 to 0.29 & 0.29 to 0.10 \\
\hline 2. & Moderate & 0.30 to 0.49 & 0.49 to 0.30 \\
\hline 3. & strong & 0.50 to 0.69 & 0.50 to 0.69 \\
\hline 4. & Very strong & 0.70 to 0.89 & 0.89 to 0.70 \\
\hline 5. & perfect & 0.90 to 0.99 & 0.99 to 0.90 \\
\hline 6. & Very Perfect relationship & 1.00 above & 1.00 above \\
\hline
\end{tabular}

As indicated in Table 4, teacher effectiveness was significant, positive and very strong correlated with supportive leadership. In addition, it was strong correlated with participative leadership and achievement-oriented leadership. Finally, teacher effectiveness was moderate correlated with directive leadership. This means that, to a great extent, an increase in the supportive leadership is associated with an increase in the level of teacher effectiveness; and to a strong extent, an improvement in participative and achievement-oriented leadership is associated with an increase in the teacher effectiveness. However, directive leadership had the weakest association with teacher effectiveness.

\section{Discussion of the Result}

The findings of the present study are-

1) Supportive leadership was at the highest agreement level. It might be because of school work normally consisted of clear structure and repetitive. Supportive leadership found to be utilized in encouraging the teachers to work as well as personal life. Therefore, principal should be friendly to their teachers by praising and encouraging them especially on important occasions.

2) Participative leadership is suitable to apply in school administration when principals are facing vague and unclear work situation.

3) In order to promote participative leadership, Principal should assign teachers to participate in decision making process, listen to teachers' opinions and encourage them to discuss in group.

4) Principals have to determine challenging objectives for the teachers to participate. They should know how to stimulate teachers to search for innovative way to improve and develop their work continuously.

5) Teachers will be able to work independently without waiting for principals' instruction or command. Although directive leadership was in the last order, Principals also need to use directive leadership when there is new program or policy by instructing the work technique to the teachers.

6) Teachers in the present study found to be highly satisfied. They are satisfied because of their Principals supported and encouraged them to further study. They also participated in training or field trip study for promotion purposes.

7) Teachers attempted to develop themselves in improving their knowledge and teaching methods or techniques by attending seminar until they did not have time to take care of their students with full efficiency can be one of reason to explain student quality was low.
8) The finding of the relationship between leadership style of Principal and teacher effectiveness indicates that the correlation is positively related.

In summary, among the four types of leadership style, supportive leadership style had the strongest with teacher effectiveness while directive leadership style had the weakest with teacher effectiveness. This is possible due to Principal who utilize supportive leadership will help teachers to overcome their work problems thus teachers will have morale in working which will lead to their working effectiveness.

\section{References}

[1] Anastasi, A. (1988). Psychological Testing (6 $6^{\text {th }}$ ed.). New York; McMillan Publishing Company.

[2] Ausubel, D.P. Novak, J.D. and Hanesion H. (1978), Educational Psychology - A Cognitive View. (2 ${ }^{\text {nd }}$ ed.), New York, Halt Rinehar and Winston, Inc.

[3] Best, J.W. and Kahn J.V. (2001), Research in Education, ( $7^{\text {th }}$ ed.), New Delhi; Prentice Hall of India.

[4] Bruner, J. (1960), Learning and Thinking, Harward Education Review, in Ausubel, D.P. Novak, J.D. and Hanesion H. (1978), Educational Psychology - A Cognitive View. (2 ${ }^{\text {nd }}$ ed.), New York; Halt Rinehar and Wintson, Inc.

[5] Kaul, L. (1984), Methodology of Educational Research, New Delhi; Vikas Publishing House Pvt. Ltd.

[6] Kerlinger, F.N. (1978), Foundation of Behavioral Research, New Delhi; Surjeet Publications.

[7] Lindergren, H.C. (1960), Educational Psychology in the Class Room. ( $1^{\text {st }}$ Ind. Ed.), Japan; Tuttle Publishing Company.

[8] Mangal, S.K. (1992), Teaching of Science, $\left(2^{\text {nd }}\right.$ ed.), New Delhi; Arya Book Depot, Karol Bagh. 